\title{
Awareness and readiness of Covid-19 among Bangladeshi residents: A rapid rise period study Mili Saha ${ }^{1}$, Goutam Saha,**
}

${ }^{1}$ Faculty of Arts, Department of English, Jagannath University, Dhaka 1100, Bangladesh ${ }^{2}$ Faculty of Science, Department of Mathematics, University of Dhaka, Dhaka 1000, Bangladesh

${ }^{1}$ Email: milisahadoll@gmail.com

Corresponding author e-mail: *gsahamath@du.ac.bd

\begin{abstract}
This article explores the knowledge about preventions, perceptions of infections, and the responsive actions to the Covid-19 situation of the young age groups residing in Bangladesh. Quantitative data were collected online using an MCQ questionnaire from around 932 participants. Results show the population is generally aware of the symptoms, keeping social distance by staying home and are concerned about re-spreading after the lockdown period. However, they are quite unsure about the possible medicines frequently talked about in the media and the necessity of avoiding animal protein.
\end{abstract}

Keywords: Individual, awareness, Covid-19, transmission, infection.

\section{Background}

Bangladesh detected her first Covid-19 infected patients on 8 March, which began with three in number. To the date, it has increased to 2456 on day forty-one, which is the sixth week and indicates the fourth phase of infection (Moral, 2020) called 'Sustained Human-to-Human Transmission' (WHO, 2009). The total number of death has reached 100 including ten deaths and around 300 new infections every day, which indicates the rapid rise period. However, the government has locked-down the highly affected areas and a general leave has been declared to keep all the private and public business and service farms remain closed. In spite of all the steps taken by the state, Covid-19 is still a health issue that should be prevented perceptively by the individuals. This is more about a personal preclusion than authority care to reduce the infection. Hence, we attempted to study the way Bangladeshi people, especially the young generations, are aware of the symptoms.

People are generally willing to maintain social distance and quarantine which can slow down the infection, although they have high anxiety about possible infection, which can be reduced through increasing awareness and addressing mental health issues (Roy et al., 2020). Most of the participants are young at the age in this study and younger individuals are more likely to be asymptomatic when infected and could be unaware they are putting others at risk' (Dong et al. 2020). On the other hand, chances of infection and the severity of illness is much direr with aged people (Zhou et al., 2020). However, hasty lifting of lock-down can promote a secondary peak while lifting lock-down gradually can flatten it (Prem et al. 2020).

Studying individual awareness can motivate people to practice the preventive measures discussed in the research and alert them in turn, in addition to knowing about the practices of a large population to avoid mass contamination.

\subsection{Research design}

This research has been executed in Bangladesh and an online questionnaire was prepared using one of the popular Google tools called Google Forms. The link to the questionnaire was saved for future use. We ensured the participants that the given personal information and opinion will be kept confidential.

Research questions:

The research questions include three aspects of the pandemic spreading rapidly in the country:

a. Knowledge about the symptoms and cure

b. Actions performed to practice prevention

c. Insights about spreading the virus

\section{Participants:}

Most of these participants have a minimum educational background which is a Higher Secondary School Certificate level and use any one of the below mentioned online platforms. Our goal was to reach a bigger audience in order to elicit maximum responses from the participants. 


\section{Data Collection:}

We provided the participants with the link using different online platforms including Facebook, Messenger, Google talk, email, and requested them to share the link with their friends and relatives on any social media so that they can respond as well. Data collection began at 10 a.m. on 17 April, 2020 and ended at 10 a.m. on 20 April, 2020. In addition, we requested participants' demographic information comprising gender identity, marital status, and place of residence. 565 male and 367 female in a total of 932 participants responded to the online survey. Among all, 574 participants belong to the age group ranging from 18 to 25 years, 349 of them belong to the age group ranging from 26 to 49 years, and only 9 participants are at the age group of 50 years and above. Also, 679 participants identify themselves as single and the remaining 253 of them are married. Besides, 514 respondents live in the Dhaka division which is the most infected region in the country and other 418 participants live outside the Dhaka division.

Data Analysis:

Later the data have been examined and categorized by the percentage of the agreement, disagreement, and personal preferences in each question. The conclusion evaluates and discusses these referring to the standard choices needed to prevent the fatal disease.

\subsection{Results and discussion}

\section{a. Knowledge}

In response to the first question, $78.76 \%$ respondents report of the complete awareness about the varied symptoms of Covid-19 and common flu while $14.80 \%$ are still unsure and $6.44 \%$ are not aware of the differences as shown in Fig. 1, which can be either fatal or stressful for them.

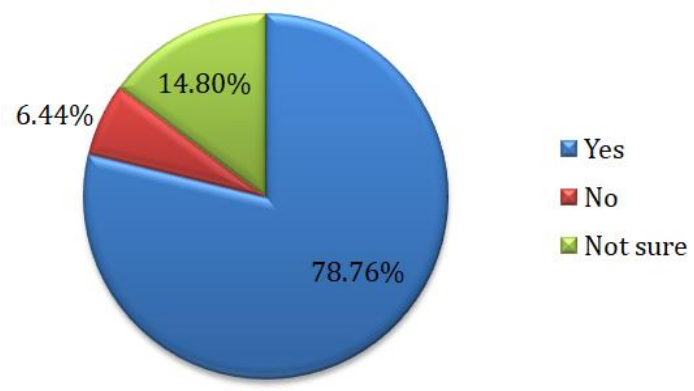

Figure 1: Symptoms of Covid-19 and common flu
Table 1

\begin{tabular}{lccc}
\hline Respondent Types & Yes $(\%)$ & No $(\%)$ & $\begin{array}{c}\text { Not sure } \\
(\%)\end{array}$ \\
\hline \multicolumn{5}{c}{ Gender } \\
\hline Male & 75.22 & 9.03 & 15.75 \\
\hline Female & 84.2 & 2.45 & 13.35 \\
\hline \multicolumn{5}{c}{ Age groups } \\
\hline $26-49$ & 76.48 & 41 & 94 \\
\hline 50 and over & 81.95 & 19 & 44 \\
\hline \multicolumn{5}{c}{100} & 0 & 0 \\
\hline Dhaka division & Place of residence \\
\hline $\begin{array}{l}\text { Outside Dhaka } \\
\text { division }\end{array}$ & 72.30 & 5.05 & 12.65 \\
\hline
\end{tabular}

Females, old age groups (50 years and above), and the population living in greater Dhaka are more aware of the differences between the symptoms of Covid-19 and other common flu than the male, younger, and the population living outside Dhaka who are most confused about the Covid-19 symptoms too.

Also, Fig. 2 reveals that the majority of people $(59.76 \%)$ are unsure about any proposed or available medicines that can be effective to treat the infected persons. $24.36 \%$ of them absolutely discard the idea of reliable medicine while $15.88 \%$ believe if they are infected, these medicines can help. This confirms the other results demonstrating a particular number of people perceive the severity through media focus, which might be wrong in reality.

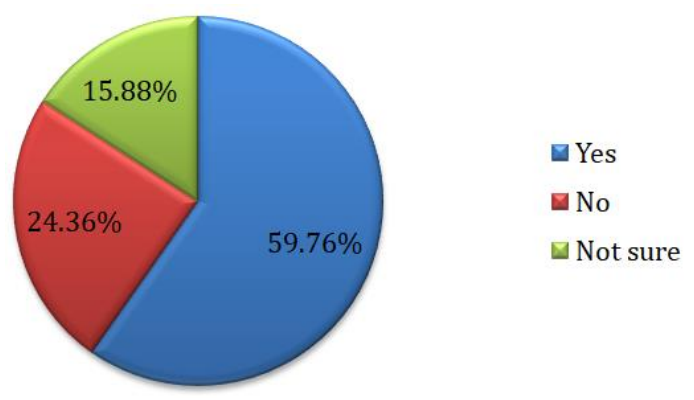

Figure 2: Proposed medicines for Covid-19 Table 2

\begin{tabular}{llll}
\hline $\begin{array}{l}\text { Respondent } \\
\text { Types }\end{array}$ & Yes (\%) & No (\%) & $\begin{array}{c}\text { Not sure } \\
(\%)\end{array}$ \\
\hline \multicolumn{4}{c}{ Gender } \\
\hline Male & 19.47 & 24.25 & 56.28 \\
\hline Female & 10.35 & 24.52 & 65.12 \\
\hline \multicolumn{4}{c}{ Age groups } \\
\hline $18-25$ & 16.55 & 22.82 & 60.63 \\
\hline $26-49$ & 15.19 & 27.22 & $57 . .59$ \\
\hline 50 and over & 0 & 11.11 & 88.89 \\
\hline \multicolumn{5}{c}{ Place of residence } \\
\hline Dhaka division & 13.82 & 24.90 \\
\hline $\begin{array}{l}\text { Outside Dhaka } \\
\text { division }\end{array}$ & 18.42 & 23.68 \\
\hline
\end{tabular}


More males, young age groups (18-25), and people from outside Dhaka believe in the medicines presented in media than the female, older and Dhaka resident participants while the most hesitant group is the old aged population.

b. Actions

Fig. 3 shows that a great majority of the respondents (77.68\%) assure us by keeping 1.5 meters distance apart from other people while $8.91 \%$ of them keep less distance and rest $13.41 \%$ are unsure, which defines the careless movement in the community.

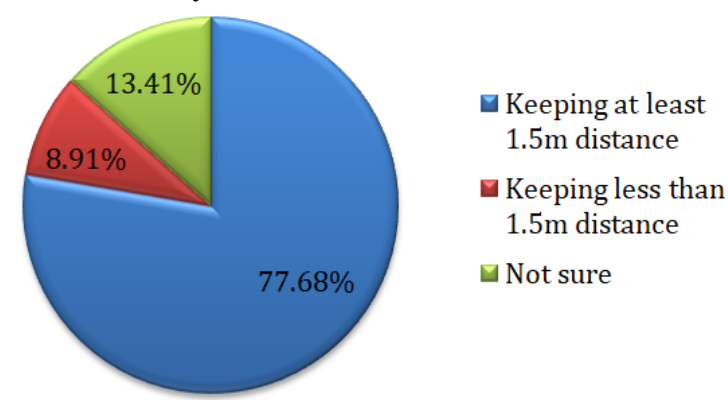

Figure 3: Social distancing

Table 3

\begin{tabular}{|c|c|c|c|}
\hline \multirow[b]{2}{*}{ Respondent Types } & \multicolumn{3}{|c|}{ Keeping } \\
\hline & $\begin{array}{c}\text { Keeping at } \\
\text { least } 1.5 \mathrm{~m} \\
\text { distance } \\
(\%)\end{array}$ & $\begin{array}{c}\text { less } \\
\text { than } \\
1.5 \mathrm{~m} \\
\text { distance } \\
(\%)\end{array}$ & $\begin{array}{l}\text { Not } \\
\text { sure } \\
(\%)\end{array}$ \\
\hline \multicolumn{4}{|c|}{ Gender } \\
\hline Male & 74.87 & 10.27 & 14.87 \\
\hline Female & 82.02 & 6.81 & 11.17 \\
\hline \multicolumn{4}{|c|}{ Age groups } \\
\hline $18-25$ & 77.53 & 8.19 & 14.29 \\
\hline $26-49$ & 77.65 & 10.03 & 12.32 \\
\hline 50 and over & 88.89 & 11.11 & 0 \\
\hline \multicolumn{4}{|c|}{ Place of residence } \\
\hline Dhaka division & 78.99 & 8.56 & 12.45 \\
\hline $\begin{array}{l}\text { Outside Dhaka } \\
\text { division }\end{array}$ & 76.08 & 9.33 & 14.59 \\
\hline
\end{tabular}

Again female, old, and non-Dhaka residents groups are keeping more social distance than male, young, and Dhaka-residents groups who are most confused about maintaining the infection detachment.

Since $52.36 \%$ of participants are staying home and $34.23 \%$ coming out once a week, it seems those $13.41 \%$ of participants who go for daily shopping are at a greater risk as described in Fig. 4.

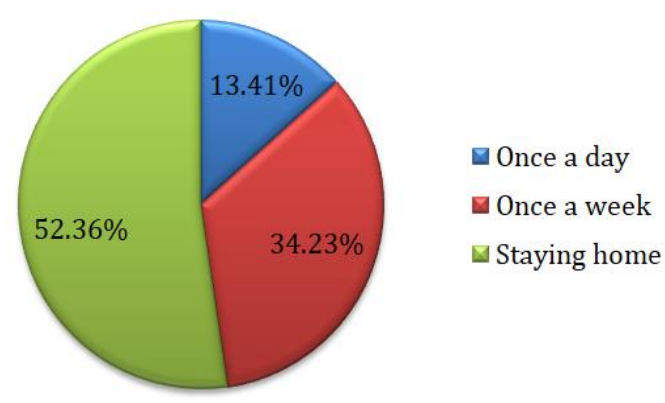

Figure 4: Staying home

Table 4

\begin{tabular}{lccc}
\hline $\begin{array}{c}\text { Respondent } \\
\text { Types }\end{array}$ & $\begin{array}{c}\text { Once a } \\
\text { day }(\%)\end{array}$ & $\begin{array}{c}\text { Once a } \\
\text { week }(\%)\end{array}$ & $\begin{array}{c}\text { Staying } \\
\text { home }(\%)\end{array}$ \\
\hline \multicolumn{4}{c}{ Gender } \\
\hline Male & 19.82 & 43.54 & 36.64 \\
\hline Female & 3.54 & 19.89 & 76.57 \\
\hline \multicolumn{4}{c}{ Age groups } \\
\hline $26-49$ & 11.50 & 31.01 & 57.49 \\
\hline 50 and over & 16.62 & 39.83 & 43.55 \\
\hline \multicolumn{5}{c}{11.11} & 22.22 & 66.67 \\
\hline $\begin{array}{l}\text { Dhaka division } \\
\text { division }\end{array}$ & Place of residence \\
\hline
\end{tabular}

As usual, male, mid-young age (26-49 years) and non-Dhaka resident groups come out of the home more frequently than female, early-young and old aged as well as the Dhaka-resident groups while female and old age groups are staying home mostly.

In spite of being remarkably alert about keeping social distance and not coming in contact with community members, the majority section of the research population $(81.65 \%)$ are relaxed about eating animal protein including eggs, meat or fish while $7.84 \%$ are super conscious about such transmission and have been avoiding eggs and milk as shown in Fig. 5. Also, another group consisting of $10.51 \%$ keep away from meat and fish. Therefore, the majority of people are at great risk in case the local animal transmission begins.

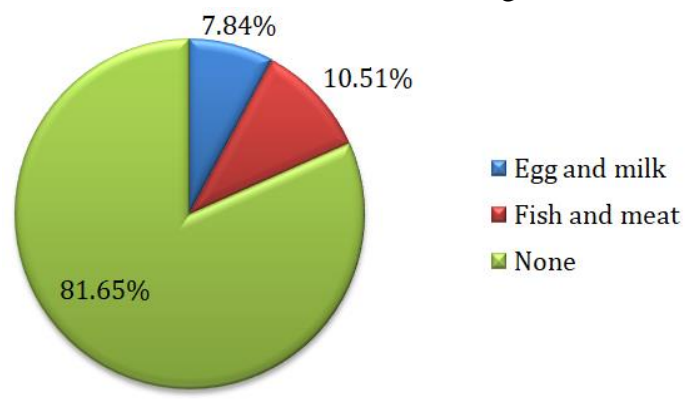

Figure 5: Avoiding animal protein 
Table 5

\begin{tabular}{lccc}
\hline $\begin{array}{c}\text { Respondent } \\
\text { Types }\end{array}$ & $\begin{array}{c}\text { Egg and } \\
\text { milk }(\%)\end{array}$ & $\begin{array}{c}\text { Fish and } \\
\text { meat }(\%)\end{array}$ & $\begin{array}{c}\text { None } \\
(\%)\end{array}$ \\
\hline Gender \\
\hline Fale & 10.44 & 11.33 & 78.23 \\
\hline \multicolumn{5}{c}{ Female } & 3.81 & 9.26 & 86.92 \\
\hline $18-25$ & Age groups \\
\hline $26-49$ & 16.72 & 10.80 & 80.84 \\
\hline 50 and over & 7.16 & 10.32 & 82.52 \\
\hline \multicolumn{5}{c}{0} & 0 \\
\hline Dhaka division & Place of residence & 100 \\
\hline $\begin{array}{l}\text { Outside Dhaka } \\
\text { division }\end{array}$ & 7.37 & 10.51 & 81.13 \\
\hline
\end{tabular}

Surprisingly old age groups are least concerned about consuming animal proteins to prevent Covid19 infection, next comes the female groups who avoid less animal protein than the male, and more Dhaka residents avoid animal protein than nonDhaka residents.

Another positive preventative measure that a great majority of the population $(67.17 \%)$ avail is always disinfecting things and taking a bath right after returning home. However, $27.04 \%$ of respondents take this measure less frequently and $5.79 \%$ population do it seldom as shown in Fig. 6, which leaves the risk of infecting the home environment unintentionally and reduces the chance of escaping it.

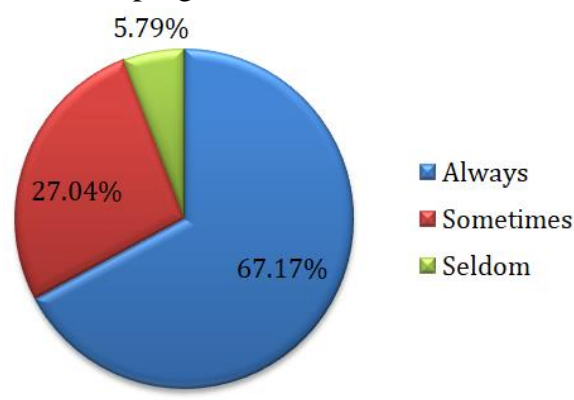

Figure 6: Cleaning and disinfecting

Table 6

\begin{tabular}{lccc}
\hline $\begin{array}{c}\text { Respondent } \\
\text { Types }\end{array}$ & $\begin{array}{c}\text { Always } \\
(\%)\end{array}$ & $\begin{array}{c}\text { Sometimes } \\
(\%)\end{array}$ & $\begin{array}{c}\text { Seldom } \\
(\%)\end{array}$ \\
\hline \multicolumn{5}{c}{ Gender } \\
\hline Male & 57.70 & 34.51 & 7.79 \\
\hline Female & 81.74 & 15.53 & 2.72 \\
\hline \multicolumn{5}{c}{ Age groups } \\
\hline $18-25$ & 64.11 & 29.44 & 6.45 \\
\hline $26-49$ & 72.49 & 22.64 & 4.87 \\
\hline 50 and over & 55.56 & 44.44 & 0 \\
\hline \multicolumn{5}{c}{ Place of residence } \\
\hline $\begin{array}{l}\text { Outside Dhaka } \\
\text { division }\end{array}$ & 74.51 & 20.82 \\
\hline
\end{tabular}

Regarding taking bath and disinfecting things after coming back from shopping, female, mid- young age, and Dhaka-residents are more careful then the counter groups of male, early-young and old as well as non-Dhaka residents, while the male group is the least and old age group, is the most aware regarding the precaution.

As Fig. 7 shows, majority of the participants $(51.06 \%)$ only avoid cold food items and drinks as prevention from the infection, although $44.56 \%$ of them are more cautious about drinking warm water to stop the virus living inside the body and $4.38 \%$ are only taking steam as they thought it can help them to prevent the virus.

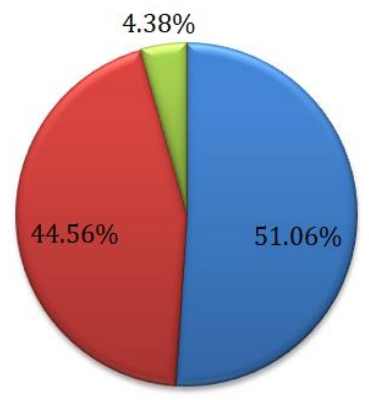

$\square$ Avoiding cold foods and drinks

D Drinking warm water

$\llbracket$ Taking steam

Figure 7: Prevention and Cure

Table 7

\begin{tabular}{lccc}
\hline $\begin{array}{c}\text { Respondent } \\
\text { Types }\end{array}$ & $\begin{array}{c}\text { Avoiding } \\
\text { cold foods } \\
\text { and drinks } \\
(\%)\end{array}$ & $\begin{array}{c}\text { Drinking } \\
\text { warm water } \\
(\%)\end{array}$ & $\begin{array}{c}\text { Taking } \\
\text { steam } \\
(\%)\end{array}$ \\
\hline \multicolumn{4}{c}{ Gender } \\
\hline Male & 49 & 45.7 & 5.3 \\
\hline Female & 54.15 & 42.86 & 2.99 \\
\hline Age groups \\
\hline $26-49$ & 50.93 & 44.93 & 4.14 \\
\hline 50 and over & 52.45 & 43.02 \\
\hline \multicolumn{5}{c}{83.33} \\
\hline Dhaka division & 48.29 & 46.67 \\
\hline $\begin{array}{l}\text { Outside Dhaka } \\
\text { division }\end{array}$ & 54.36 & 40.70 \\
\hline
\end{tabular}

More female, mid-young aged and non-Dhaka resident participants avoid cold food and drinks, more male, old aged and Dhaka-resident participants drink warm water, and more male old aged and non-Dhaka resident respondents take steam to prevent Covid-19 infection than the counter groups. Although female groups are quite aware of avoiding cold foods and drinks, they are least responsive to drinking warm water and taking steam.

Figure 8 shows that the greater majority of the respondents $(42.51 \%)$ prefer to take all preventive measures than testing $(54.81 \%)$ if they discover Covid-19 symptoms in them. The worst risk is still $2.67 \%$ of respondents plan to hide about the 
potential infection from others, which can be detrimental for their surroundings.

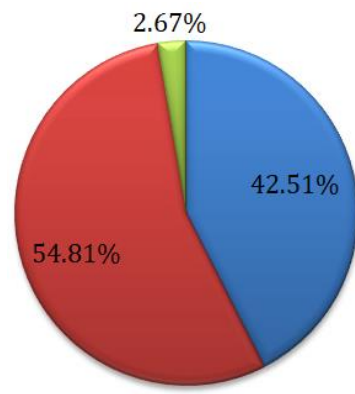

$\square$ Taking all preventive measures

a Testing

$\square$ Hiding from others

Figure 8: Measures after infection

Table 8

\begin{tabular}{|c|c|c|c|}
\hline $\begin{array}{l}\text { Respondent } \\
\text { Types }\end{array}$ & $\begin{array}{c}\text { Taking all } \\
\text { preventive } \\
\text { measures }(\%)\end{array}$ & $\begin{array}{c}\text { Testing } \\
(\%)\end{array}$ & $\begin{array}{c}\text { Hiding } \\
\text { from } \\
\text { others } \\
(\%)\end{array}$ \\
\hline \multicolumn{4}{|c|}{ Gender } \\
\hline Male & 42.22 & 54.89 & 2.89 \\
\hline Female & 43.10 & 54.88 & 2.02 \\
\hline \multicolumn{4}{|c|}{ Age groups } \\
\hline $18-25$ & 57.97 & 39.34 & 2.69 \\
\hline $26-49$ & 47.88 & 49.42 & 2.70 \\
\hline 50 and over & 66.67 & 33.33 & 0.0 \\
\hline \multicolumn{4}{|c|}{ Place of residence } \\
\hline Dhaka division & 43.98 & 52.58 & 3.44 \\
\hline $\begin{array}{l}\text { Outside Dhaka } \\
\text { division }\end{array}$ & 40.76 & 57.48 & 1.76 \\
\hline
\end{tabular}

Both male and female groups are equally interested in trying the preventive measures, testing, and hiding about it if they are found infected. The old age group is most interested in preventive measures; non-Dhaka residents are aware of testing most; Dhaka-residents are prone to hide most. However, the old age group is not at all interested in hiding.

The critical part of the findings includes $43.13 \%$ of participants rely on home care than $41.63 \%$ of those who prefer to shift to hospital initially after finding themselves as Covid-19 positive, as shown in Fig. 9. This involves the local people's reliance on the state and physician's policy for treating Covid-19 patients. However, $15.24 \%$ population is indecisive regarding the matter, which could drop them in chaos and delay or cure once they are infected.

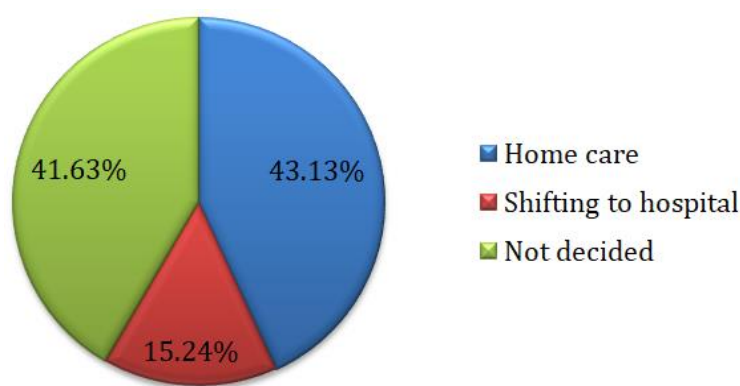

Figure 9: Treatment of infection Table 9

\begin{tabular}{lccc}
\hline $\begin{array}{c}\text { Respondent } \\
\text { Types }\end{array}$ & $\begin{array}{c}\text { Home } \\
\text { care }(\%)\end{array}$ & $\begin{array}{c}\text { Shifting to } \\
\text { hospital (\%) }\end{array}$ & $\begin{array}{c}\text { Not } \\
\text { decided } \\
(\%)\end{array}$ \\
\hline \multicolumn{4}{c}{ Gender } \\
\hline Male & 42.65 & 41.59 & 15.75 \\
\hline Female & 43.87 & 41.69 & 14.44 \\
\hline \multicolumn{5}{c}{ Age groups } \\
\hline $26-49$ & 31.71 & 51.39 & 16.90 \\
\hline 50 and over & 62.18 & 26.07 & 11.75 \\
\hline \multicolumn{5}{c}{33.33} & 22.22 \\
\hline Dhaka division & Place of residence \\
\hline $\begin{array}{l}\text { Outside Dhaka } \\
\text { division }\end{array}$ & 36.50 & 37.35 \\
\hline
\end{tabular}

The mid young age groups are most prone to stay home if infected while early young age groups prefer shifting to hospital in such cases. And, old age groups are the most indecisive which is a risk too. Also, Dhaka residents rely more on home care and non-Dhaka residents prefer to move to the hospital than staying home. However, gender shows no considerable effects on choosing Covid19 treatment among the respondents.

Regarding social services, such as raising awareness and informing the community, the $77.86 \%$ participants mainly use the online platform and social media keeping social distance while $15.16 \%$ try to make people aware through practicing the health rules and $6.98 \%$ report about demonstrating the safety tasks to instruct people how to save from infecting as presented in Fig. 10.

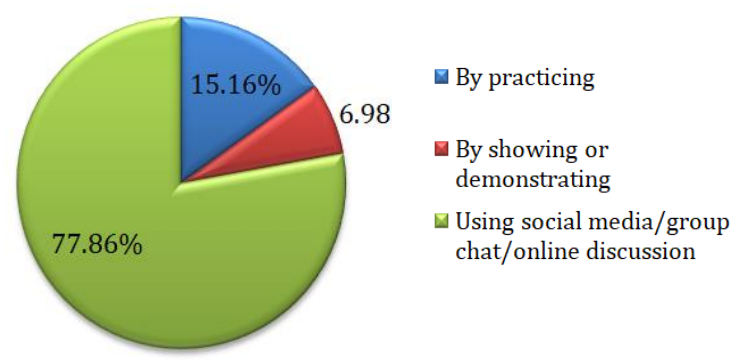

Figure 10: Social awareness work

Responses regarding raising mass awareness during the pandemic period demonstrate the 
groups' almost equal share of work using any particular mode of demonstration. However, old age groups are ahead with practicing preventions, early-young age group is best with online work and mid-age groups demonstrate more than other groups.

Table 10

\begin{tabular}{lccc}
\hline $\begin{array}{c}\text { Respondent } \\
\text { Types }\end{array}$ & $\begin{array}{c}\text { By } \\
\text { practicing } \\
(\%)\end{array}$ & $\begin{array}{c}\text { By showing } \\
\text { or } \\
\text { demonstrating } \\
(\%)\end{array}$ & $\begin{array}{c}\text { Using social } \\
\text { media/group } \\
\text { chat/online } \\
\text { discussion } \\
(\%)\end{array}$ \\
\hline \multicolumn{4}{c}{ Gender } \\
\hline Male & 14.39 & 7.19 & 78.42 \\
\hline Female & 16.34 & 6.65 & 77.0 \\
\hline \multicolumn{5}{c}{ Age groups } \\
\hline $26-49$ & 13.36 & 6.15 & 80.49 \\
\hline 50 and over & 17.94 & 8.53 & 73.53 \\
\hline \multicolumn{5}{c}{25.0} & 0.0 & 75.0 \\
\hline Dhaka division & 15.08 & 6.35 & 78.57 \\
\hline $\begin{array}{l}\text { Outside Dhaka } \\
\text { division }\end{array}$ & 15.25 & 7.75 & 77.0 \\
\hline
\end{tabular}

Disinfecting things and washing hands will be the second priority to the participants $(29.08 \%)$ while keeping a social distance is the highest priority $(47.42 \%)$ as shown in Fig. 11, which the World Health Organization emphasizes. Although wearing safety masks and gloves is least preferred after the lock-down period, this is the most common practice at this rapid rise period.

Figure 11: Post-lock-down-safety

Table 11

\begin{tabular}{lccc}
\hline $\begin{array}{c}\text { Respondent } \\
\text { Types }\end{array}$ & $\begin{array}{c}\text { Wearing } \\
\text { safety } \\
\text { masks/gloves } \\
(\%)\end{array}$ & $\begin{array}{c}\text { Maintaining } \\
\text { social } \\
\text { distance } \\
(\%)\end{array}$ & $\begin{array}{c}\text { Disinfecting } \\
\text { hands and } \\
\text { things } \\
\text { frequently } \\
(\%)\end{array}$ \\
\hline \multicolumn{4}{c}{ Gender } \\
\hline Male & 26.73 & 49.38 & 23.89 \\
\hline Female & 22.89 & 44.41 & 32.70 \\
\hline \multicolumn{5}{c}{ Age groups } \\
\hline 26-25 & 23.69 & 50.70 \\
\hline 50 and over & 23.21 & 42.12 & 25.61 \\
\hline \multicolumn{5}{c}{22.22} & 44.44 \\
\hline Dhaka division & Place of residence & 33.63 \\
\hline Outside Dhaka & 23.35 & 43.19 \\
Division & 23.68 & 52.63 & 23.46 \\
\hline
\end{tabular}

However, male participants outperform the female group regarding the post-lock-down awareness and the data shows the male group is more likely to wear safety masks and gloves and maintaining social distance while the female group is prone to washing hands and disinfecting things more frequently than the male group. Also, young groups and non-Dhaka residents outperform the counter old aged and Dhaka-resident groups with more awareness about the upcoming risk.

\section{c. Perceptions}

Figure 12 suggests $64.48 \%$ of respondents believe getting closer to infected persons is the most potent source of Covid-19 transmission in Bangladesh while secondary contact through infected person's used items is the next possible risk of contamination. And, 5.48\% of participants are concerned with air transmission, which indicates this group's extreme awareness about the virus's existence in the environment.

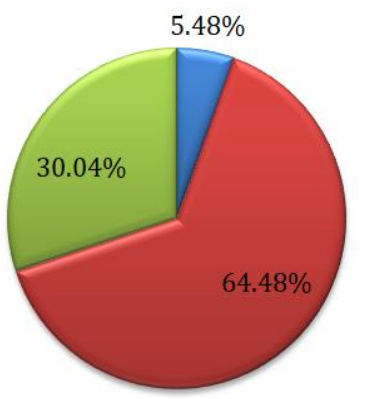

$$
\begin{aligned}
& \square \text { Exposure to air } \\
& \square \text { Getting close to } \\
& \text { someone } \\
& \text { infected } \\
& \text { Touching things } \\
& \text { used by infected } \\
& \text { persons }
\end{aligned}
$$

Figure 12: Source of contamination

Table 12

\begin{tabular}{lccc}
\hline $\begin{array}{c}\text { Respondent } \\
\text { Types }\end{array}$ & $\begin{array}{c}\text { Exposure } \\
\text { to air } \\
(\%)\end{array}$ & $\begin{array}{c}\text { Getting } \\
\text { close to } \\
\text { someone } \\
\text { infected } \\
(\%)\end{array}$ & $\begin{array}{c}\text { Touching } \\
\text { things used } \\
\text { by infected } \\
\text { persons } \\
(\%)\end{array}$ \\
\hline \multicolumn{4}{c}{ Gender } \\
\hline Male & 4.25 & 66.90 & 28.85 \\
\hline Female & 7.36 & 60.76 & 31.88 \\
\hline \multicolumn{5}{c}{ Age groups } \\
\hline $26-49$ & 5.75 & 65.51 \\
\hline 50 and over & 5.16 & 62.75 & 28.75 \\
\hline \multicolumn{5}{c}{62.09} \\
\hline Dhaka division & Place of residence \\
\hline $\begin{array}{l}\text { Outside Dhaka } \\
\text { division }\end{array}$ & 6.23 & 63.62 \\
\hline
\end{tabular}

Groups have comparable beliefs about the local sources of contamination, although female participants tend to believe more in air transmission and touching things used by infected persons than males. The old age group completely ignores the possibility of air transmission.

The research participants are generally anxious about the negative social attitudes, negligence, and rudeness showed towards the Covid-19 patients in Bangladesh. Figure 13 shows that $48.06 \%$ of them are frustrated, $40.24 \%$ are afraid and $11.70 \%$ are angry to see such insolence and humiliation including abundance, refusal, and limited access to 
treatment, avoidance, and rejection from both family and society.

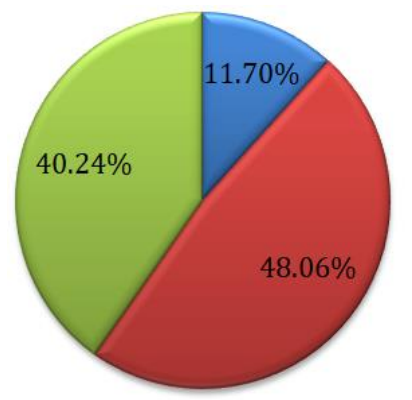

$\square$ Angry

Frustrated

$\square$ Scared

Figure 13: Social attitude towards infected persons Table 13

\begin{tabular}{llll}
\hline $\begin{array}{c}\text { Respondent } \\
\text { Types }\end{array}$ & $\begin{array}{c}\text { Angry } \\
(\%)\end{array}$ & $\begin{array}{c}\text { Frustrated } \\
(\%)\end{array}$ & $\begin{array}{c}\text { Scared } \\
(\%)\end{array}$ \\
\hline \multicolumn{5}{c}{ Gender } \\
\hline Male & 10.97 & 48.85 & 40.18 \\
\hline Female & 12.81 & 46.87 & 40.33 \\
\hline \multicolumn{5}{c}{ Age groups } \\
\hline $18-25$ & 11.15 & 46.34 & 42.51 \\
\hline $50-49$ & 12.32 & 50.43 & 37.25 \\
\hline \multicolumn{5}{c}{ and over } & 22.22 & 66.67 & 11.11 \\
\hline Dhaka division & Place of residence \\
\hline $\begin{array}{l}\text { Outside Dhaka } \\
\text { division }\end{array}$ & 13.04 & 48.05 & 38.91 \\
\hline
\end{tabular}

The groups have similar reactions to the negative social attitudes, rudeness, and negligence shown to the Corona patients in Bangladesh, although the old age group is more angry and frustrated, although least scared with this attitude.

Figure 14 shows a great majority of the respondents $(49.25 \%)$ are concerned that the virus will re-spread as soon as the lock-down is relaxed. A very minor group (13.84\%) believe the situation will become normal while $36.91 \%$ of them are unsure about the choices.

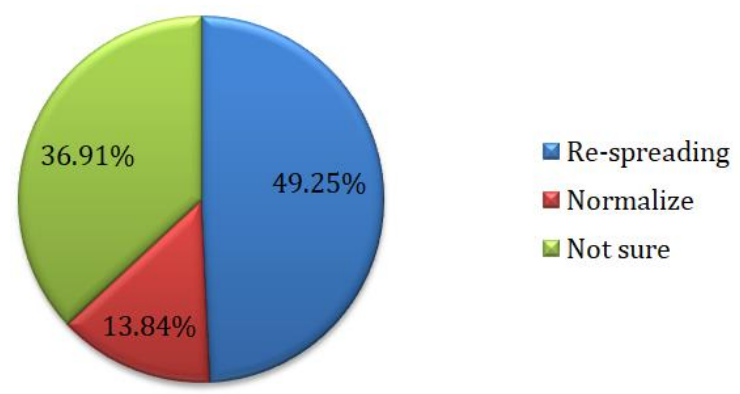

Figure 14: Post lock-down re-spreading

Table 14

\begin{tabular}{lccc}
\hline \multicolumn{1}{c}{ Response } & $\begin{array}{c}\text { Re-spreading } \\
(\%)\end{array}$ & $\begin{array}{c}\text { Normalize } \\
(\%)\end{array}$ & $\begin{array}{c}\text { Not sure } \\
(\%)\end{array}$ \\
\hline \multicolumn{4}{c}{ Gender } \\
\hline Male & 48.67 & 15.22 & 36.11 \\
\hline Female & 50.14 & 11.72 & 38.15 \\
\hline \multicolumn{5}{c}{ Age groups } \\
\hline $18-25$ & 46.69 & 15.33 & 37.98 \\
\hline
\end{tabular}

\begin{tabular}{lccc}
\hline $26-49$ & 53.87 & 11.75 & 34.38 \\
\hline 50 and over & 33.33 & 0.0 & 66.67 \\
\hline \multicolumn{4}{c}{ Place of residence } \\
\hline Dhaka division & 50.39 & 14.20 & 35.41 \\
\hline $\begin{array}{l}\text { Outside Dhaka } \\
\text { division }\end{array}$ & 47.85 & 13.40 & 38.76 \\
\hline
\end{tabular}

Female participants are more anxious about Covid-19 re-spreading after the lock-down is lifted up and are less optimistic about normalizing the situation than the male respondents. Also, the old age group is least concerned about re-spreading, least hopeful about normalizing, and most confused about choosing any of the options.

\section{Conclusion}

Findings show Bangladeshi female and old age groups are, on the whole, socially and psychologically connected, although physically distanced and thus, are preventing the risks of infection. However, young age groups are comparatively less aware of the symptoms, social distancing, and outing, which indicates the greater risk involved with the males and population living in the divisions other than Dhaka. Although female participants are more aware regarding many aspects including cleaning, disinfecting, and further outbreak, they are less active in self-care and avoiding animal meat or fish which might be unsafe. The most significant findings of the study reveal that the old age group is the most alert group, males are the most vulnerable with less care, people living outside Dhaka have less knowledge and preventive measures against the deadly virus, young age group is more optimistic while the female respondent group is prepared most of all participants. Hence, the more awareness and preparation programs should be introduced regarding Covid-19 for the people residing in the remote and underdeveloped areas where mass communication through online technology is limited. The overall findings demonstrate that 16$20 \%$ of respondents comprising mainly the young male groups are at high risk of infection.

\section{Conflict of Interest}

The authors do not report any financial or personal connections with other persons or organizations, which might negatively affect the contents of this publication and/or claim authorship rights to this publication. 


\section{Publication Ethic}

Submitted manuscripts must not have been previously published by or be under review by another print or online journal or source.

\section{Acknowledgement}

We acknowledge Rhun Saha for proofreading the article.

\section{References}

Cheng, K. K., Lam, H.T., Leung, C.C. (2020). Wearing face masks in the community during the COVID-19 pandemic: altruism and solidarity. THE LANCET.doi:10.1016/S01406736(20)30918-1. Retrieved on 22 April, 2020 from Link

https://www.thelancet.com/journals/lancet/arti cle/PIIS0140-6736(20)30918-1/fulltext

Dong, Y., Mo, X., Hu, Y., Xin, Q., Jiang, F., Jiang, Z., \& Tong, S. (2020). Epidemiological characteristics of 2143 pediatric patients with 2019 coronavirus disease in China. Pediatrics, e20200702. doi: 10.1542/peds.2020-0702.

Moral, S. (2020). Bangladesh at 4th stage of coronavirus infection. Published in Daily Prothom Alo. Link:

https://en.prothomalo.com/bangladesh/bangla desh-at-4th-stage-of-coronavirus-infection

Prem, K., Liu, Y., Russell, T.W., Kucharski, A.J., Eggo, R.M., Davies, N., Jit, M., \& Klepac, P.
(2020). The effect of control strategies to reduce social mixing on outcomes of the COVID-19 epidemic in Wuhan, China: a modeling study. Lancet Public Health, doi:10.1016/S2468-2667(20)30073-6.

Roy, D., Tripathy, S., Kara, S.K., Sharmaa, N., Vermaa, S.K., \& Kaushalb, V. (2020). Study of knowledge, attitude, anxiety \& perceived mental healthcare need in Indian population during COVID-19 pandemic. Asian Journal of Psychiatry, 51, $102083 . \quad$ doi: 10.1016/j.ajp.2020.102083.

World Health Organization (2009). Current WHO phase of pandemic alert for Pandemic (H1N1). Link:

https://www.who.int/csr/disease/swineflu/phas e/en/

Zhou, F., Yu, T., Du, R., Fan, G., Liu, Y., Liu, Z., Xiang, J., Wang, Y., Song, B., Gu, X., Guan, L., Wei, Y., Li, H., Wu, X., Xu, J., Tu, S., Zhang, Y., Chen, H., \& Cao, B. (2020). Clinical course and risk factors for mortality of adult in patients with COVID-19 in Wuhan, China: a retrospective cohort study. Lancet, 395, 1054-1062. doi: 10.1016/S01406736(20)30566-3. 
Appendix

Questionnaire

1. Your gender:

A. Male, B. Female

2. Your age group:

A. $18-25$, B. $26-49$, C. $50+$

3. Your marital status:

A. Married, B. Unmarried/Single

4. 4. Your place of residence:

A. Dhaka division, B. Outside Dhaka division

5. Are you confirmed about the differences between the symptoms of COVID-19 and the common flu?

A. Yes, B. No, C. Not sure

6. How do you maintain social distance from other people everywhere?

A. Keeping less than $1.5 \mathrm{~m}$ distance, B. Keeping at least $1.5 \mathrm{~m}$ distance, C. Not sure

7. How frequently do you go outside for any specific purposes like buying foods/medicines etc?

A. Once a day, B. Once a week, C. Staying home

8. What is the most possible way to be infected in Bangladesh?

A. Getting close to someone infected, B. Touching things used by infected persons, C. Exposure to air

9. Which animal protein are you avoiding to keep safe from COVID-19?

A. Eggs and milk, B. Fish and meat, C. None

10. Do you disinfect your things and take a bath instantly after coming back from outside?

A. Always, B. Sometimes, C. Seldom

11. Do you believe any of the proposed medicines could help to fight against COVID-19?

A. Yes, B. No, C. Not sure

12. What precautions do you intend to have to protect yourself after the lockdown?

A. Wearing safety masks/gloves, B. Maintaining social distance, C. Disinfecting hands and things frequently

13. What will you do if you find the COVID-19 symptoms in you?

A. Taking all preventive measures, B. Testing, C. hiding from others

14. What do you plan to cure if you find yourself COVID-19 positive initially?

A. Home care, B. Shifting to hospital, C. Not decided

15. How do you feel to see social attitudes and rudeness towards the COVID-19 positive patients?

A. Frustrated, B. Scared, C. Angry

16. How do you raise positivity and awareness among others?

A. Using social media/group chat/online discussion, B. By practicing, C. By showing or demonstrating

17. What risks do you predict after the lockdown is over?

A. Respreading, B. Normalize, C. Not sure

18. What safety measures you avail to prevent infection?

A. Drinking warm water, B. taking steam, C. Avoiding cold foods and drinks 